\title{
A POLICY SHIFT IN THE EUROPEAN NEIGHBOURHOOD: UKRAINE'S DYNAMICS VERSUS EUROPE
}

\section{AVRUPA'NIN KOMŞULARINDA POLITIKKA DEĞİŞiMI: AVRUPA'YA KARȘI UKRAYNA'NIN DINNAMIKLERI}

Yrd. Doç. Dr. Sezgin MERCAN, Başkent Üniversitesi, İIBF, Siyaset Bilimi ve Uluslararası İlişkiler Bölümü, mercan @ baskent.edu.tr

Yrd. Doç. Dr. Barış GÜRSOY, Adnan Menderes Üniversitesi, Nazilli İIBF, Uluslararası İlişkiler Bölümü, baris.gursoy@adu.edu.tr.

\begin{abstract}
The European Union has regarded a stabilising neighbourhood for the regional and international security. It pursues to build a secure neighbourhood via international cooperations. Ukraine is a significant state for the European Union to build a secure neighbourhood by means of the European Neighbourhood Policy and Eastern Partnership. But Ukraine's 2014 civil conflicts revealed that this state has different internal dynamics to reverse European oriented policies. This article displays that the European Neighbourhood Policy and its power has been limited and reduced to regional and local axis, although the European Union has stabilising foreign policy instruments for its neighbours.
\end{abstract}

Key Words: European Neighbourhood Policy, Ukraine, Institutionalism, Formal Democratization, Identity

$\ddot{\boldsymbol{O}} \boldsymbol{z}$

Avrupa Birliği bölgesel ve uluslararası güvenlik için istikrar sağlayan bir komşuluk ilişkisini önemsemektedir. Uluslararası işbirlikleri aracıllğ̆lyla güvenli bir komşuluk inşa etme peşindedir. Ukrayna Avrupa Birliği için, Avrupa Komşuluk Politikası ve Doğu Ortaklı̆̆ aracılı̆̆ıla güvenli bir komşuluğun inşasında önemli bir devlettir. Fakat Ukrayna'nın 2014'deki iç çatışmaları, bu devletin Avrupa yönlü politikaları tersine çeviren farklı iç dinamikleri olduğunu ortaya çıkarmıştır. Bu makale, Avrupa Birliği, komşularında istikrar sağlayan dış politika araçlarına sahip olmasına ră̆men, Avrupa Komşuluk Politikası'nın ve nüfuzunun bölgesel ve yerel eksenlerle sinırlı olup onlara indirgendiğini göstermektedir.

Anahtar Kelimeler: Avrupa Komşuluk Politikası, Ukrayna, Kurumsalcılık, Biçimsel Demokratikleşme, Kimlik

\section{INTRODUCTION}

The European Union (EU) is considered a stabilising neighbourhood which copes with the international security challenges. It tries to manage a secure neighbourhood via international cooperation which bases on partner countries. For the EU, Ukraine is a priority partner state in the 2004 European Neighbourhood Policy (ENP) (As of May 12, 2004, Commission of the European Communities website) and 2009 Eastern Partnership. But Ukraine's 2014 
revolution has once more exhibited that this state has different vivid dynamics which have the potential to deflect European oriented policies toward Russian axis. This article explains that although the EU has stabilising political practices and governance in its neighbourhood, conceptualising of ENP has been limited and reduced to regional and local challenges like Ukraine crisis.

The EU has a unique property by which international politics is conducted in Europe. This property is its promotion of social learning process. Learning is a basic pillar of Europeanisation, including negotiation. It is an important feature where the EU works as a platform for the convergence of ideas and policy transfer between member, candidate and also partner states. "EU guidelines combined with specific timetables; action to be undertaken at the national and regional level; benchmarking and sharing of best practice; qualitative and, when appropriate, quantitative indicators; period monitoring, evaluation, and peer review organised as mutual learning processes" (Bulmer and Radaelli 2003, 11-13).

The EU is a significant agent which is able to reconceptualize and socialize Eastern states and governance via its common policies, partnerships, integration model and democratic conditionality. The important example of this situation is the case of Ukraine. This article argues that Ukraine has started to deteriorate the EU's aspirations and conditionality. It analysis how the ENP's capacity to influence regional and local governance has been challenged by the Russian affect with reference to the changing politics of Russia which entails to strengthen its international and regional power. In this way, the weakness of the EU's international and regional power and how the EU has begun to move from maintaining and promoting its own values and interests in international area are highlighted through the case of the Ukraine crisis.

This article exhibits that the quality of the ENP, based on inside and outside dynamics in Europe, has deficiency to stabilize Ukraine's political practices to maintain its power as a foreign policy instrument of the EU and promote resolutions based on principles of unitary state in European neighbourhood. Although the EU conditionality (Pridham 2008, 372) has led to the prioritization of territorial integrity, civilian actors and instruments concerned with neighbourhood policy, problems remain concerning the sustainability of their enhanced role. This article seeks to advance research on the potantial impact of national institutions and domestic political dynamics of Ukraine on ENP and the reverse influence of international developments and actors on the domestic context of Ukraine's foreign policy. It is concluded that Ukraine and Russia have the potential to reduce ENP's legitimacy, authority and credibility in the eyes of Eastern countries, unless the EU revises regional policies in terms of considering local dynamics.

\subsection{The Institutional Origin of the $E U$ and Ukraine Relations}

The EU-Ukraine Summit, which was on October $27^{\text {th }}$, 2006, made clear that EU membership was ruled out (Lane 2007, 498). Former President of the European Commission Jose Manuel Barrosso said that "Ukraine is not ready and we are not ready" (Lasas 2014). Ukraine has 
never been promised accession status by the EU. The EU-Ukraine relations have been regulated by ENP. But, the European neighbourhood is at the croosroads because of new challenges which have arisen in recent months.

According to the ENP's working documents, partner countries have faced with new and increasingly complex realities and also pressures which have become diverse challenges for them. The ENP and its policy instruments are constructed as a framework within which the EU works with its partners. But the challenges require the policy to respond better for expectations and needs of each partner state against complex realities. In this situation, results might be in a serious disadvantage for the EU. For instance, the EU is providing an additional EUR 3.3 million to help the most vulnerable population affected by the conflict in Eastern Ukraine. This has increased the EU's humanitarian funding to EUR 11.05 million since the beginning of the conflict within the context of the provision of shelter, food and non-food assistance, health services and protection. EU financial assistance was the highest annual level in 2013, at EUR 2.65 billion, for the ENP partners. Ukraine's share in EU financial support to partner countries was EUR 142 million in 2007, 138.6 million in 2008, 116 million in 2009, 126 million in 2010, 65 million in 2011, 149 million in 2012, 199 million in 2013 to support for democratic development and good governance, regulatory reform and administrative capacity building, and infrastructure development. The country's total was EUR 935.6 million within these years (As of March 27, 2014, European Union External Action Service website; March 27, 2014, European Commission website; November 12, 2014, European Commission website).

Although the ENP structure reflects economic advantages, it also reflects two disadvantages for Ukraine. Firstly, Ukraine has a risk of being excluded from the decision making process of the EU because of Neighbourhood Agreement based relations. Secondly, it faces the problem of not being in receipt of structural funds in case of political and economic crisis. On the other side, Ukraine might have the economic advantages of a large free market and an open visa regime. Free market regime would not alienate Ukraine preserving the links with Russia. Such a policy would enable the EU to reach economic and security objectives without destabilisation problems which are exploded by enlargement (Lane 2007, 503). Also Y1ldiz argues that Russia forces Eastern Partnership countries such as Ukraine, Moldovia and Georgia not to sign Partnership Agreements with EU to keep them under its hegemony (for details see Y1ldiz 2015, 141-162).

At this point, the EU's treatment on Ukraine should be identified with how it evaluates the regional position of this country. Because it is decisive in the formulation of foreign policy in Ukraine. The EU defined Ukraine in the category of Newly Independent States, not as a Central or East European countries. However, all Ukraine's Western neighbours were accepted as Central or East European countries. The EU's attitude affected Ukraine's fuzzy self-perception and foreign policy orientation negatively. Although the EU's 2004 enlargement is considered to integrate Western, Central and Eastern Europe, Ukraine has not been seen as a part of this integration (Solonenko 2009, 711-714). In that case, what should be 
understood from the European point of view while studying interactions and experiences of the EU in terms of external frontiers?

From a rational institutionalist perspective ${ }^{1}$, it is possible to claim that the EU is seeking to extend its own particular model of liberal democracy to its neighbours by using its institutions. It should be emphasized that the EU follows to promote its values through the ENP for self-interest and uses ENP as an instrument for benefit maximization. EU institutions, the Council, the Commission, etc., which implement the ENP are seen to provide constraints and opportunities to achieve the goals. Ukraine is the best example of this situation as an external partner of the EU. The official EU documents related with the strategies and objectives of the ENP reflect benefit maximization attempts (Eriş 2012, 253-255). For instance, Ukraine's alignment with common foreign and security policy declarations rose from $37 \%$ in 2012 to $47 \%$ in 2013. It is beneficial for the EU to put Ukraine into 'the tunnel', but it is not enough. According to the EU, although this development is positive, the change in figures does not necessarily reflect a qualitative change in building more coherence in foreign policy between Ukraine and the EU. The EU wants more without transaction costs in developing coherence. Progress on public finance management for EU budget support, progress on border management and the demarcation of state borders, implementation of the integrated border management strategy are basic pillars of benefit maximization attempts (As of March 27, 2014, European Commission website and Eilstrup-Sangiovanni 2006, 194, 195).

It is important to note that some progress has been made in the field of 'formal democratization' in terms of the establishment of democratic institutions at polity level. But little progress has been made in the field of 'substantive democratization' with reference to the creation of transparency, accountability and participation in policy processes in Ukraine (Casier 2011, 957). EU promoted democratic reforms have progressed more on the polity level than on the governance level. This also indicates that the EU follows to promote its values for self-interest by using ENP as an instrument (Casier 2011, 957).

At this point, it is necessary to deal Goeffrey Pridham's concepts of formal democracy and substantive democracy (Pridham 2000, 4). Formal democracy reflects institutional and procedural characteristics of a regime emphasizing fair and free votes of the citizens. It involves establishing rules, procedures and institutions for the purpose of arriving at political decisions. Substantive democracy reflects principles and practical elements for societal control over policy processes with reference to the distribution of power. It can be accepted a way of regulating power relations to maximize the opportunities for individuals to influence society (Casier 2011, 959). According to substantive democracy, formal procedures can not provide necessary conditions for democracy alone. EU democracy promotion in Ukraine indicates formal democratization process (Casier 2011, 959 and Pridham 2000, 4). The EU's strategy of democracy promotion can be accepted as a reinforcement strategy (Casier 2011, 960).

\footnotetext{
${ }^{1}$ In EU studies, rational institutionalism recognizes the importance of EU members in shaping EU foreign policy, in fact EU institutions play an independent role in the process (for details see Popescu 2011).
} 
The lack of social learning is an unignorable problem between the EU and Ukraine. The people-to-people dimension was underdeveloped within the framework of the ENP arrangements. For instance, the EU was reluctant to launch visa policy and its visa-free roadmap which were offered to the countries of the Western Balkans. This situation limits the EU's influence on strengthening the commitment of the Ukrainian political and social actors to democratic reforms (Solonenko 2009, 717, 718).

The EU's first priority in 1990s was to deepen European integration on the basis of membership network. Conflictual Balkans, the evolving transatlantic relations and the uncertain fate of Russian reforms were challenges for the integration. The issue of eastern enlargement was debated with the Czech Republic, Hungary, Poland, and Slovakia. The western periphery of the former Soviet Union had not entered the integration. This situation of the EU had contributed to the decline of reform spirit in Ukraine (Molchanov 2004, 457).

Although the reform spirit has the potantial to decline, Ukraine has three factors which link it with the West. These are geography, politics and culture. Geographically, Ukraine belongs with Europe obviously (Molchanov 2004, 452). On the other hand, the Ukrainian political actors perceive relations with the EU from political and security perspectives, rather than in economic terms. There was a demand by the Ukrainian political actors for the EU conditionality to form geopolitical security for Ukraine's independence. But the EU's deficiency as a geopolitical security promoter and basic anchor for Ukraine, affected modernization negatively in Ukraine (Langbein and Wolczuk 2012, 867, 868). Politically, it is an important ally with the West and contributor as the fourth largest partner in the Coalition forces in Iraq for instance after Great Britain, Poland and Italy.

The problem can be presented with reference to the condition in which there is an ambiguity about the EU's will on Ukraine's membership and Ukraine's readiness for the membership. Ukraine's determination to apply for EU membership dates back to the 1993 'Main Directions of Ukraine's Foreign Policy'. In 1994, Ukraine's first post-Soviet President, Leonid Kravchuk and, in 1996, Leonid Kuchma declared joining the EU as a key foreign policy priority. But, sociological polls display that European identity remains different for the majority of Ukranian population. The support for Ukraine's European integration efforts is weak inside the society and government which grows feeling of distance between Ukraine and and the European integration (Molchanov 2004, 460). European integration or Europeanization means to approach the EU's regulations, policies, norms, values, institutionalizations, political, economic and social structures for Ukraine. Besides, Europeanization necessitates a transformation of these factors with reference to the EU.

The question of approximation of Ukraine to the EU dominated the agenda of the 2000's between them. For instance, this question was seen in Copenhagen Summit between the EU and Ukraine in 2002 and Yalta Summit in 2003. After the Copenhagen Summit, the State Council on European and Euro-Atlantic Integration of Ukraine had become functional coordinating activities with the Committee for European Integration of the Ukrainian Parliament. In 2003, the National Programme for Approximation of the Legislation of 
Ukraine to that of the EU passed into law for conformity with the EU's acquis and creation of the Coordination Council headed by the Prime Minister (Molchanov 2004, 458, 459). These were the bureaucratic developments which had a few effects on Europeanization.

It is possible to think that Ukraine's lack of success to realize Europeanization can be explained by domestic factors within the country. The EU's Partnership and Co-operation Agreement with Ukraine was signed in 1998. Financial assistance was provided for political and economic reforms. Associate membership to the EU was the main foreign policy objective for Ukraine. However, at that time, the Ukraine leadership had to consider domestic economic and political problems. Ukraine's political parties did not manage to implement a coherent policy and reform programme on Europeanization or European integration. They did not build a legislative majority on integration also. This situation revealed failures to pursue the reforms needed for the implementation of the Agreement. The serious failures were widespread corruption within the Ukrainian administration and organized cross-border crime (Eriş 2012, 251-253).

The other problem was about problematic leadership in Ukraine which contributed to the increase in differences between Ukraine and the EU. Kuchma leadership was a significant example of this. On the other hand, Viktor Yuschenko adopted a pro-Western strategy and his presidency increased the possibility to transform Ukraine towards the Europeanization. After Yuschenko, the EU added new titles to its Action Plan to strengthen the relationship especially on justice, home affairs and security issues. But, it did not change the EUUkrainian relations to a new institutional level which could contribute the Ukraine'splace in Europe. However, to motivate Ukraine towards Europeanization, membership aspirations were necessary rather than accession to the European market. The EU's attitude did not change in EU-Ukraine Summits in early 2010's in terms ofthe prospect of EU membership. Ukraine's active engagement in the Eastern Partnership ${ }^{2}$ initiative was emphasized by the Council of the EU in 2010. At that time, the serious differences between Yushchenko and Prime Minister Yulia Tymoshenko led to more instability. After that, Yushcenko was eliminated and Viktor Yanukovych won the presidency. With Yanukovych's presidency, the era of the Orange Revolution and the Europeanization of Ukraine was over and Russia influence became more visible. These developments were also indicators of the ENP's limited transformative effect in Ukraine. Ukrainians could not foresee the costs of there forms and acquis adaptation or Europeanization. This uncertainity led to opposition to the EU membership within Ukraine (Eriş 2012, 251-253).

The EU did not apply conditionality with respect to Ukraine. But it did in 2005. This was an incurability of the EU to offer Ukraine. Neither did the EU apply any monitoring, nor did it propose any reform guidelines or timetables to Ukraine. In 2005, the ENP introduced conditionality with reference to the EU-Ukraine Action Plan. The attractive offer to Ukraine within the ENP is to be a part of free trade area (Solonenko 2009, 716). In that case, the

\footnotetext{
${ }^{2}$ Eastern Partnership is a complemantary and consolidated joint initiation with same values, principles and instruments of ENP. It is designed for Armenia, Azerbaijan, Belarus, Georgia, the Republic of Moldova and Ukraine which are also partners of ENP. (As of May 7, 2009, Council of European Union website).
} 
Ukraine's offer to the ENP should be revealed to enlighten domestic effects of partner countries on the EU practices generally.

Within the context of the impact of national institutions and domestic political dynamics of partner countries as Ukraine on ENP, there are five problems with the ENP which cause inefficiency in its implementation (Eriş 2012, 249-251). Firstly, the lack of the incentive of EU membership is the main reason which makes the ENP unable to promote democracy in partner countries. The absence of membership perspective weakens EU's legitimacy and ability to promote its norms and values to the neighbours. Lack of membership perspective weakens the power of politicians in neighbouring countries to make the necessary reforms. Secondly, it becomes necessary for a partner state to ask what the costs of aligning its legislation with the acquis. It is not obvious what the actual award is for enacting EU conditionality in the ENP. The EU also lacks to provide sufficient financial resources to its neighbourhood because of the financial burden of EU enlargement and the Euro zone problems. Thirdly, the ENP promotes one-sided dependence in an inherently unbalanced relationship. The dominance of EU rules and the dependence of associates on EU concessions are built into the structure of the bilateral negotiations. Fourthly, the EU faces the problem of building a neighbourhood with cohesiveness. By including the ex-Soviet countries, the ENP stretches over a very large geographical area and encompasses a wide diversity of countries. Fifthly, the Action Plans of the ENP are also problematic. Asking partner countries to approximate to the EU's values and norms and enabling them to participate in the EU's internal market is expected to help increase prosperity and security in the neighbourhood. But, the acquis may not be an appropriate framework for countries struggling with basic economic reforms (Eriş 2012, 249-251). These problems lead to inefficiencies of the EU's Ukraine policy.

\subsection{Russian Anchor in the Relations Between Ukraine and the EU}

After the Cold War, democratization and liberalization processes were spreading values in the communist countries. Ukraine adopted these processes in the beginning of its independence. However, it also continued close relations with Russia. The relations between Ukraine and Russia did not come to an end after the collapse of the Eastern Bloc. While the Orange Revolution in 2004 emphasized the place of Ukraine in international area with reference to the Western practices, pro-Western prospects were not in secure conditions. Ukraine has prefered to join NATO and the EU. But it has been out of these institutions. Such conditions placed Russia in a significant position in Ukraine's foreign policy. Also, according to Arman and Mengüaslan, as long as Russia and Ukraine continue keeping strong economic ties, a radical split will not be observed between them (for details see Arman and Mengüaslan 2015, 59-81). This was the dilemma of Ukraine which made difficult to join the Western institutions and to move further away from Russia (Proedrou 2010, 446, 447).

Ukraine's foreign policy practices exhibit that conflicting interests impede the state from either joining with the West or aligning with Russia. At the same time, Ukrainian elites and citizens have been divided on the future orientation of Ukraine. Whereas the eastern part of 
Ukraine supports aligning with Russia, the western part supports joining with the Western integrations and institutions. At this point, the foreign policy of Ukraine remains in conclusive merely without a certain direction. There are three factors which restrict Ukraine foreign policy direction. First one is systemic constraints; second one is societal and state interests; third one is identity politics (Proedrou 2010, 447, 448).

With reference to systemic constraints, geography manifests itself. Geography's importance arises from the presence, policies and attitudes of Russia from Central Asia to the Caucasus for Ukraine which is overshadowed by them (Proedrou 2010, 447, 448). Geography is a dependency agent to Russia for Ukraine in terms of external practices and internal reforms. For instance, Russia's Black Sea Fleet is stationed in the port of Sevastopol, Crimea based to an agreement between two parties. The agreement was to expire in 2017. Ukrainian officials would like to get full control of the port. But the Yanukovich government extended the agreement in 2010 for 25 years. It is obvious that Russia would like to keep its military base as a strategical and symbolical power asset. The other power asset was the backyard of Russia in terms of Central and Eastern European countries (Proedrou 2010, 447, 448).

The problem in this context was threatening movements of the European countries to Russia's backyard in which its interests were kept. The 1999 enlargement of the NATO which included Czech Republic, Hungary, Poland and the 2004 enlargement which included Bulgaria, Estonia, Latvia, Lithuania, Romania, Slovakia, Slovenia became a starting point for Russia complaint. These were hostilities to Russian interests according to Russian leaders. Because they, specifically Russian Foreign Minister Sergey Lavrov (Bodner 2014), accused the EU of creating a sphere of influence in Eastern Europe. This problem has revealed that the EU's principals as the rule of law, human rights, democracy, and economic interdependence can not only be accepted as integrants of European integration because of the realpolitic's effect. Weak and divided Ukraine could be taken control by Russian forces. So, Russia took Crimea ${ }^{3}$ from Ukraine. The EU saw this development as an indicator of a Russian threat near its and also NATO's borders. It was also about geopolitics and its effect on Russia-Ukraine-EU relations. Because, it is a basic principle that great powers are sensitive to potential threats near their territories. Russia has had an attitude of acting with reference to realism in international area against the European countries which have tried to move according to liberalism by means of the EU's social-engineering effect on Ukraine (Mearshimer 2014, 7789).

On the other hand, Russian energy sources affect Russia-Ukraine relations. Energy sources raise Ukraine's dependency to Russia. Ukraine's industry is energy consuming and inefficient because of its outmoded facilities. The Russian cutting off gas supply to Ukraine has the potantial of evoking energy shortages. It is also about Ukrainian economy because of debt to Gazprom for the gas. Energy sources supply became a Russian reminder to stand out for

\footnotetext{
${ }^{3}$ Crimea was annexed by Russian Federation in March 2014. After the annexation, Russia increased its military capacity in the peninsula gradually. The EU did not recognize the illegal annexation of Crimea and Sevastopol by Russia.
} 
political and economic preferences of Ukrainians towards Russia rather than the West (Proedrou 2010, 447, 448).

With reference to societal and state interests, it is conspicuously seen that the Ukrainian economy needs a modernization process for sustainability in terms of investments and infrastructure. The rising gas prices and inefficient industry make Ukrainians increasing pay for imports from Russia. But, capital, technology, and know-how inflow from the Western countries, more specifically from the EU, has the potantial of contributing Ukrainians economic and also political conditions. However, it is not easy to define Ukrainian national interests clearly. The interests of different sectors which influnce Ukrainian domestic politics designate its foreign policy. In Ukraine, there are two different domestic forces who prefer coordination and cooperation with the West on the one side and prefer opposition to such initiatives and implementations on the other. Kuchma pursued a balance policy between the two sides. This policy brought Ukraine closer to the EU and NATO. According to him, Russia should not be upset because of Ukraine's necessities. He also gave lots of privileges to the business sector. Clientelism and corruption were inevitable in such an environment. Ukranians began to demand a Ukraine without Kuchma. Orange Revolution clarified the direction towards more pro-Western policies after 2004 rising pro-Western Yuschenko to the presidency and Tymoshenko to the prime ministry (Proedrou 2010, 448, 449 and Ash 2009, 26).

Society and interest related differences and disagreements can arise within the pro-Western parties in Ukraine. Political competition did not begin until the 2004 presidential elections in Ukraine. Therefore, it was not until 2004 that the change of political leaders occurred in Ukraine on the way for democratic reforms (Solonenko 2009, 719). After the Orange Revolution, the pro-Western alliance broke down between Yuschenko and Tymoshenko toward political competition. Reform process for the Ukrainian constitution strengthened the authority of the Prime Minister. This authorisation made difficult for Yuschenko and Tymoschenko to coordinate foreign policy practices. Yuschenko gave attention to the presidential authorities to eliminate Tymoschenko's popularity and increase his own popularity. At that time, Yanukovich were taking heart from the eastern part of Ukraine and its industrial tycoons. It should not be forgotten that Yuschenko and pro-Western policies were supported by those in 2004 to attract foreign investments (Proedrou 2010, 450, 451).

But they faced with industrial restrictions because of sectoral concentration in the East of Ukraine including coal-mining, metal and steel production, machine building and chemicals. This had the potantial to make Ukranian government economically delicate in relation to the Eastern Ukraine and Russia. Russia became the second big market for Ukrainian exports after the EU market. The EU share in country's exports is $26.5 \%$. The Russia share in country's exports is $23.8 \%$. The EU share in country's imports is $35.1 \%$. The Russia share in country's imports is $30.2 \%$ (As of 2014, World Trade Organization website). Besides, within the context of EU trade with ENP's East, Ukraine's share was $51.5 \%$ in 2012 and $51 \%$ in 2013 (As of March 27, 2014, European Commission website). In this context, economic integration into the EU could provide industrial benefits to Ukraine. But, capital ties are also significant. 
Russian investors have extensive shares in Ukraine's industry. Besides, the enterprises' dependence on statesubsidies makes them 'government behind' blocking economical liberalization movements. Without liberalization, it is difficult for Ukraine to benefit from economic integration with the EU (Proedrou 2010, 450).

On the other side, the Ukraine and Russia trade disagreement made Ukraine obstructed economically and politically. Russia blocked all imports from Ukraine in August 2014. This fact was a warning which indicated a 'trade war' to prevent Ukraine from signing an Association Agreement with the EU. It was a part of Russia's general attitude to prevent Ukraine's economic integration with the EU and promote 'Eurasian' movement. If Ukraine signs the Association Agreement with the EU, it can not be a member of Russian planned 'Economic Union' which includes Eurasiatic tendencies on the basis of market, trade and economic ties (Popescu 2013). This tendency has an institutional process. In 2007, a treaty setting up the Eurasian Customs Union between Russia, Belarus and Kazakhstan was signed. In 2010, common customs tariff was launched; Eurasian Customs Union Commission began to work. In 2011, internal physical border controls were eliminated. In 2012, Single Economic Space was inaugurated. At the end, in January $1^{\text {st }}, 2015$, the start of the Eurasian Economic Union was planned (Dragneva and Wolczuk 2012, 5). "Ukraine, with its population of 45 million, was supposed to play a key role in the Eurasian Economic Union, on account of its economic clout and the place it occupies in the Russian imagination and worldview" (Vitkine 2014). "Without Ukraine, Russia ceases to be a Eurasian empire, as the former US national security adviser Zbigniew Brzezinski wrote in The Grand Chessboard, in 1997" (Vitkine 2014). But Ukraine signed the Agreement in March 2014. With this Agreement, it can be thought that "the dream of a geopolitical Eurasia died in Ukraine. 'Eurasia' will remain confined to its existing members, and a few small and poor states that will not necessarily make the union stronger" (Popescu 2014, 34).

"Russia has begun to compete in a domain where the EU has exercised a monopoly until now" (Dragneva and Wolczuk 2012, 9). This competition has a dimension of identity politics as well. With reference to identity politics, it is seen that Ukraine is a divided country historically on the basis of national ideological stance which reflects on its foreign policy. The West of Ukraine had been under the control of Poland, Austro-Hungary and Czechoslovakia, whereas the East and South of Ukraine were under the control of the Russian empire from 1793 to 1917. Another division was in the Second World War, while the eastern Ukrainians fought with the Russian Army, Western Ukrainians were cooperating with the Axis countries. The eastern Ukrainians have seen Russians and Ukrainians as brothers with reference to common kinship, history, culture, language and Russian minority (Dragneva and Wolczuk 2012, 452, 453).

In the 1920s and 1930s, the essential time for contemporary Ukrainian national identity, the Soviet government did not have an absolute influence on the formation of Ukrainian national identity. Most Ukrainians who prefer Western and European Ukraine were part of the independent Polish, Czechoslovak and Romanian states. In the Habsburg Empire and interwar Poland, West Ukrainian national identity was shaped and imposed this type of identity on all 
Ukrainians (Brudny and Finkel 2011, 817). Soviet influence on Western Ukraine was realized after the World War II. Nevertheless, main characteristics of the Western Ukrainian identity, which based on independence, the use of Ukrainian language and anti-communist feelings, were protected against Soviet absolute influence by means of army's predominance. But, outside Western Ukraine and Kyiv, a significant number of Ukrainians did not identify themselves with the mentioned identity. They lived in developed and industrial areas of East and South Ukraine which had belonged to the Russian Empire for centuries. This East-West differentiation is basic characteristic of contemporary Ukraine's politics (Brudny and Finkel 2011, 817, 818). But, 'Putin announced that Russians and Ukrainians are 'one nation' and that throughout the vagaries of history the idea of unity between Ukraine and Russia always lived on both in the east and west of the lands where their nation lived" (Popescu 2014, 27).

A 'negative self-identification' in Ukraine, which meant to reject a Russian and an Asiatic way of life and autocratic political values, became an anchor for Western Ukrainian national identity (Brudny and Finkel 2011, 821). Nearly $78 \%$ of Ukranians see themselves as ethnically Ukranian. Only $17 \%$ see themselves ethnically Russian. But these percents do not provide sufficient information to understand which cultural identity is dominant in Ukraine. At this point, the importance of language should be emphasized. For instance, in 2004, the percentage of the population that considered themselves Russian was $34.5 \%$, the percentage of the population who considered themselves Russian speakers was $82.1 \%$ in eight Ukranian regions (Odessa, Dneppropetrovsk, Kharkov, Nikolaev, Zaporozhye, Donetsk, Lugansk, Crimea). This indicates that there is a division on ethnic identity and cultural identity in Ukraine. In other words, Ukranians' identity is under the influence of two pillars as ethnicity and culture. Culture's influence is put into action by means of language. So, it is possible to infer that there is a large Russian cultural impression in Ukraine beyond ethnic identity presence. In Ukraine, a 2012 survey exhibited that $60 \%$ of news papers, $83 \%$ of journals, 87 $\%$ of books, $72 \%$ television programs are in Russian. The internet became a promoter of Russian cultural dominance in Ukraine. The easy accessibility of the Russian mass media provides a wide promotion area for Russian in Ukraine cities while Ukrainian is used in governance, parliamentary and legal issues which are least popular in the public. This social structure reveals that the EU should concentrate on 'social dialogue' and its mechanisms between Europeans and Ukrainians. For instance, education projects can be implemented to provide unity in language on the way of strengthening the nation state in Ukraine. According to the EU, although some progress was achieved in bringing the higher education system of Ukraine closer into line with the EU, adoption of a new law on higher education advanced very slowly (Petro 2014, 5, 6, and as of March 27, 2014, website of European Commission).

Three suggestions can be advanced for Ukraine in terms of identity issues. Firstly, a form of forcible 'Ukrainianization' can be achieved. This may be associated with Europeanization of Ukraine. But, this is not easy to realize because of Russian effect and possibility of increasing regional political confrontation in Ukraine. Secondly, it is possible to have one official language while allowing local official languages as part of regional differences. Thirdly, it is also possible to have two official languages, Russian and Ukranian. In this way, equality of rights can be protected (Petro 2014, 8, 9). 
But the second and third suggestions have the potential of promoting cultural regionalism which raises division in Ukraine between central and regional governments. At this point, some ideas are appeared for rebuilding the state structure of Ukraine moving towards the understanding of self-government or federalism as a solution for identity problems. The EU should clarify its own attitude on behalf of creating a long term strategy for Ukraine and also a part of the ENP. This strategy should include an 'integrationist' approach against 'seperatists'. Essentially, identity problems have two pillars in Ukraine as internal and external ones. External pillar is about the international position of Ukraine in Europe, Eurasia or in the world. This pillar reflects Ukraine's Western inclination. Internal pillar is influenced by culture and language on which Russia has dominance. The EU should consider these pillars and organize the ENP as required by them. The two pillars underpin complex realities in Ukraine so that the EU has to compete with. The EU has to compete with Eurasianism for instance. It has reemerged in Ukraine in response to the increasing alienation between Ukraine and Russia. 'Eurasianism' is related to the image of Russia as not European but an Asiatic or semi-Asiatic power which comes from historical background. This power can be perceived as a threat to Europe (Shlapentokh 2013, 450).

Increasing tension with the West, beginning from 2008 Georgia war, has modified nationalism as the ideological framework. This nationalism has increasing elements of Russocentrism. Russia emphasized itself as surrounded by a hostile West and Muslim East. Russians developed an attachment to Orthodoxy. It was integrated into Soviet ideology from the late 1920s to the end of the Soviet regime. For instance, Russian novelist and historian Alexander Solzhenitsyn dreamed about the union of Slavic Orthodox states, Russia, Ukraine, and Belorussia, as the result of post-Soviet arrangements (Shlapentokh 2013, 460).

Most Russian intellectuals regarded Ukrainian alienation and hostility as a result of domination of nationalists inspired by anti-Russian Westerners in historical process. They believed that the majority of Ukrainians would remember that they would be an integral part of Russian civilization and remove the anti-Russians. But after the Boris Yeltsin's presidency era, Ukraine had a position against Russia. The 'Orange Revolution' of 2004 and the weakness of pro-Moscow political forces increased the alienation before the Georgia-Russian war. In the Russo-centric version of the universe and Orthodox Slavs are seen as part of an 'other' world. Slavs are seen more negatively than Europeans (Shlapentokh 2013, 460, 461). This identification can be seen on the social level which is understood by means of a statistical framework.

According to the survey in Ukraine which examine Ukranians view of Russia, percent of them responding favorable is $87 \%$ in 2002, $81 \%$ in 2007, $84 \%$ in 2011, and $35 \%$ in 2014. Percent of them responding unfavorable is $12 \%$ in 2002, $16 \%$ in 2007, $11 \%$ in $2011,60 \%$ in 2014. The survey which examines satisfaction with national conditions indicates that satisfied Ukranians percent with the way things are going is $9 \%$ in 2002, $9 \%$ in 2007, $7 \%$ in 2009, 9 $\%$ in 2011 , and $15 \%$ in 2014. Percent of Ukrainians responding dissatisfied is $89 \%$ in 2002, $88 \%$ in $2007,88 \%$ in $2009,87 \%$ in $2011,80 \%$ in 2014 . In addition to this, the survey about world's leading economic power reveals that $10 \%$ of Ukrainians say the EU in 2011 and 13 
\% in 2014. $40 \%$ of Ukrainians say the United States in 2011 and $30 \%$ in 2014 (As of 2014, website of Pew Research). These percentages denote that Ukranians' view of Russia bases on a negative tendency. In addition, satisfaction with national conditions is low in Ukraine and Ukranians see the US as a leading economic power in the world. Thus, Ukranians' settling of Russia, the EU and also their own governments can be clarified in the usefulness of the statistical framework.

According to the survey in Ukraine, most Ukranians want to maintain current borders of their countries. With $77 \%$, Ukranians want to see the country united. $14 \%$ say the regions should be allowed to secede. This survey indicates a negative attitude to the role of Russia in Ukraine. On the other hand, Ukranians are not happy with the governance of their state. $49 \%$ of Ukranians thinks that the government is bad on the way things are going in Ukraine. $41 \%$ of them think it is good. Division between West and East is considerable about the governance. $28 \%$ of Western Ukranians say the govenment's way is bad, $60 \%$ say it is good. But $67 \%$ of Eastern Ukranians say the government's way is bad, $24 \%$ say it is good. About the state's leadership, the survey revealed that Ukranians do not satisfy with the influence of foreign countries or organizations. $45 \%$ Ukranians determines the EU as a best organization which has a good inluence for Ukraine. $33 \%$ says it has bad influence. $67 \%$ determines Russia has a bad influnce on Ukraine and $22 \%$ says it is good. The confidence in foreign policy of Russia has decreased from $56 \%$ in 2007 to $23 \%$ in 2014. Moreover, the US is determined as good by $38 \%$ of Ukranians and as bad by $38 \%$ (As of May 8, 2014, website of Pew Research). Percentages about unitary, governance, leadership and influence of foreign countries and organizations become basic variables on the quality of the ENP and Eastern Partnership which face with deficiency to stabilize Ukraine's political practices and maintain the EU conditionality. The condition for the ENP's sustainability is context: Although the EU has stabilising political practices and governance in its neighbourhood, conceptualising of ENP and its regional power has been limited and reduced to regional and local challenges or restrictions like Ukraine's dynamics.

\section{CONCLUSION}

Association Agreement, which has built the principles of current relations with the EU, has two meanings for Ukraine. The first meaning is the agreement became an anchor for Ukraine to start adaptation process to the EU norms. The second meaning is the agreement became an indicator of Ukraine's consent to follow the EU norms. But it does not mean the prospect of membership and it does not mean ineffectiveness of Russia. Ukraine has encountered national and ethnic divisions. Such a prospect might contribute necessary conditions for political and social stability in Ukraine. But the European neighbourhood is at the croosroads because of hard challenges. As it is mentioned, neighbour countries have faced with complex realities and pressures which create difficulties for cooperation with the EU as it is in Ukraine.

As a theoretical inference, rational institutionalism indicates that the EU is seeking to extend its model of liberal democracy to its neighbours by means of bureaucratic institutions. The EU's self-interest and will for benefit maximization instrumentalize ENP and cause a 
'prototype neighbour perception'. This type of perception limits the EU practices in case of internal crisis in neighbour countries. Ukraine is the best example of this situation as an external partner of the EU. The EU does not seem to change its rational institutionalist attitude towards Ukraine by underpinning the lack of prospect on the way of democratization and social learning. Some progress has been made in the name of formal democratization like establishment of democratic institutions. But little progress has been made in substantive democratization which includes the creation of transparency, accountability and participation in Ukraine (for details see Casier 2011, 956-977). This has raised bureaucratization trap within the context of relations between the EU and Ukraine. Bureaucratization of their relations can trap them in administrative processes eliminating substantive institutional developments.

Because of domestic factors, Ukraine has not been able to succeed to realize Europeanization. Ukraine has confronted a risk which consists of weak central government because of tendency to autonomy and federation by establishing a special status in the East. Domination of central government has been limited by dependency factor of Russia in Ukraine. Cultural and economic dependency to Russia has been encouraged by Ukraine's Russian speaking regions which are also industrialized centres. Economic attraction is also a basic promoter of Russian domination on Ukraine. Customs union proposal and social security sources can be addressed as a soft link between the eastern Ukraine and Russia, while Crimea become a hard link between them.

Ukraine's foreign policy revealed that conflicting interests impede it from either joining with the West or aligning with Russia. As a significant strategy, Russia has had an attitude of acting with reference to realpolitics in international area dealing with identity politics while the EU has struggled to move toward liberal politics which includes social-engineering effect on Ukraine. Social learning necessitates that the EU should concentrate on social dialogue between Europeans and Ukrainians against Russian cultural dominance.

Although Russia has been increasing military spendings since $2004^{4}$, it has developed a power alternative on Ukraine over time. It is rational that the EU has not prefered military conflict with Russian forces. However, power alternative of Russia presents a challenge for the EU. Crimea crisis has revealed that the EU has been in a weak position to implement power politics. Conversely, Russia has executed a strategy of controlled crises against Ukraine and the West. It should not be unconsidered that the EU has a deficit to cope with global and regional crisis. European and American sanctions, particularly for Russia, base on individual and corporative restriction can not be accepted so deterrent to cope with them as well. The main point is about the competition between the Europeanism and Russianism indeed. Crimea crisis revealed competition between soft Europeanism and soft and hard Russianism. In this

\footnotetext{
${ }^{4}$ Declining military spending in the USA and Western Europe was reflected in a decline in the military-related sales of the Top 100 arms-producing and military services companies worldwide, excluding China, which fell by 4 per cent in 2012. There was a sharp increase in the arms sales of Russian companies, again reflecting the major rearmament programme being pursued by Russia (SIPRI 2014).
} 
context, The EU should clarify its own attitude by creating a political, economic and social strategy for Ukraine and the ENP. This strategy should include an integrationist approach against seperatists.

\section{REFERENCES}

Arman, Murat ve Mengüaslan, Hikmet (2015). "Avrupa Komşuluk Politikası Çerçevesinde Ukrayna Krizi”, Uğur Burç Yıldız (ed.), Avrupa Birliği’nin Dış İlişkileri: Bölgesel Politikalar, Bölgeler ve Uluslararası Aktörlerle İlişkiler, Nobel Yayınları, Ankara, 2015: 59-81.

Ash, Timothy Garton (2009). Facts Are Subversive: Political Writing From a Decade Without A Name, London: Atlantic Books.

Bodner, Matthew (2014). "Lavrov has harsh words for EU”, The Moscow Times. (17.02.2014) http://www.themoscowtimes.com/news/article/lavrov-has-harsh-words-foreu/494681.html, (accessed 17.09.2014).

Brudny, Yitzhak M., Finkel, Evgeny (2011). "Why Ukraine Is Not Russia Hegemonic National Identity and Democracy in Russia and Ukraine", East European Politics and Societies, 25 (4): 813-833.

Bulmer, Simon J., Radaelli, Claudio M. (2004). "The Europeanisation of National Policy?", Queen's Papers on Europeanisation, 1: 11-13.

Casier, Tom (2011). "The EU's two-track approach to democracy promotion: the case of Ukraine", Democratization, 18 (4): 956-977.

Commision of the European Communities (2004). "European Neighbourhood Policy: Strategy Paper", COM(2004)373 Final. (12.05.2004) http://eur-lex.europa.eu/legalcontent/EN/TXT/PDF/?uri=CELEX:52004DC0373\&from=EN, (accessed 06.06.2015).

Council of European Union (2009). "Joint Decleration of the Prague Eastern Partnership Summit", $8435 / 09$

(Presse

78). http://www.consilium.europa.eu/uedocs/cms_data/docs/pressdata/en/er/107589.pdf, (accessed 09.05.2015).

Dragneva, Rilka, Wolczuk, Kataryna (2012). "Russia, the Eurasian Customs Union and the EU: Cooperation, Stagnation or Rivalry?”, Briefing Paper, REP BP 2012/01, Chatham House.

Eilstrup-Sangiovanni, Mette (2006). Debates on European Integration, New York: Palgrave Macmillan.

Eriş, Özgür Ünal (2012). "European Neighbourhood Policy as a tool for stabilizing Europe's Neighbourhood", Southeast European and Black Sea Studies, 12 (2): 243-260.

European Commission (2014). "Neighbourhood at the Crossroads: Implementation of the European Neighbourhood Policy in 2013”, Joint Staff Working Document, SWD(2014) 99.

(27.03.2014)

http://www.eeas.europa.eu/enp/pdf/2014/regional/eastern_partnership_report.pdf, (accessed 28.09.2014).

European Commission (2014). "Neighourhood at the Crossroads: Implementation of the European Neighbourhood Policy in 2013", Joint Staff Working Document, SWD(2014) 98,

http://www.eeas.europa.eu/enp/pdf/2014/stats/statistical_annex_2014.pdf, (accessed 27.09.2014).

European Commission (2014). "Ukraine: EU boosts humanitarian assistance and recovery aid to €32 million”, Press Release, (12.10.2014) http://europa.eu/rapid/press-release_IP-141660_en.htm, (13.10.2014). 
European Commission (2014). "Implementation of the European Neighbourhood Policy in Ukraine Progress in 2013 and recommendations for action", Joint Staff Working Document, SWD(2014) 96. (27.03.2014) http://eeas.europa.eu/enp/pdf/2014/countryreports/ukraine_en.pdf (accessed 21.06.2015).

European Commission (2014). "Neighourhood at the Crossroads: Implementation of the European Neighbourhood Policy in 2013", Joint Staff Working Document, SWD(2014) 98.

(27.03.2014) http://www.eeas.europa.eu/enp/pdf/2014/stats/statistical_annex_2014.pdf, (accessed 27.06.2015).

European Commission (2014). "Implementation of the European Neighbourhood Policy in Ukraine Progress in 2013 and recommendations for action", Joint Staff Working Document, SWD(2014) 96. (27.03.2014) http://eeas.europa.eu/enp/pdf/2014/countryreports/ukraine_en.pdf (accessed 27.06.2015).

European Council Conclusions on External Relations (2015). (19.03.2015) http://www.consilium.europa.eu/en/press/press-releases/2015/03/conclusions-russiaukraine-european-council-march-2015/ (accessed 14.06.2015).

European Union External Action (2014). "European Neighbourhood Policy". (27.03.2014) http://eeas.europa.eu/top_stories/2014/270314_enp_package_en.htm,

(accessed 27.06.2015).

Hatton, Daniel (2010). "Did the Orange Revolution Change Ukraine's Geopolitical Position Regarding Russia and the West?", POLIS Journal, 3: 1-26.

Kuzio, Taras (2012). "Ukraine's relations with the West since the Orange Revolution", European Security, 21 (3): 1-19.

Lane, David (2007). "In or out of Europe? What prospects for Ukraine?", Perspectives on European Politics and Society, 8 (4): 495-504.

Langbein, Julia, Wolczuk, Kataryna (2012). "Convergence Without Membership? The impact of the European Union in the Neighbourhood: Evidence From Ukraine", Journal of European Public Policy, 19 (6): 863-881.

Lasas, Ainius (2014). "Is the EU Ready for Ukrainian Membership?", EUObserver. (25.02.2014) http://euobserver.com/opinion/123252, (accessed 25.05.2015).

Mearshimer, John J. (2014). "Why the Ukraine Crisis is the West's Fault", Foreign Affairs, 93 (5): 77-89.

Petro, Nicolai (2014). “Ukraine's Ongoing Struggle with Its Russian Identity”, World Politics Review, (06.05.2014) http://www.worldpoliticsreview.com/articles/13758/ukraine-songoing-struggle-with-its-russian-identity, (06.01.2015), 4-10.

Pew Research, Global Attitudes Project (2014). "Global Indicators Database", http://www.pewglobal.org/database/indicator/1/country/229/, (accessed 06.01.2015).

Pew Research Global Attitudes Project (2014). "Despite Concerns About Governance, Ukrainians Want to Remain One Country", http://www.pewglobal.org/2014/05/08/despite-concerns-about-governance-ukrainianswant-to-remain-one-country/, (accessed 06.01.2015).

Pollack, Mark A. (2007). "Rational Choice and EU Politics", http://www.unc.edu/euce/eusa2007/papers/pollack-m-09a.pdf: 31-55 (accessed 10.02.2015).

Popescu, Nicu (2014). "Eurasian Union: The Real, the Imaginary and the Likely", Chaillot Paper, 132, European Union Institute for Security Studies.

Popescu, Nicu (2013). "The Russia-Ukraine Trade Spat", 26. http://www.iss.europa.eu/uploads/media/Alert_Ukraine_trade.pdf, (accessed 26.05.2015). 
Popescu, Nicu (2011). EU Foreign Policy and Post-Soviet Conflicts: Stealth Interventions, New York: Routledge.

Pridham, Geoffrey (2008). "The EU's Political Conditionality and Post-Accession Tendencies: Comparisons from Slovakia and Latvia", Journal of Common Market Studies, 46(2): 365-387.

Pridham, Geoffrey (2000). The Dynamics of Democratization: A Comparative Approach, London: Continnuum.

Proedrou, Filippos (2010). 'Ukraine's foreign policy: accounting for Ukraine's indeterminate stance between Russia and the West", Southeast European and Black Sea Studies, 10(4): 443-456.

Shlapentokh, Dmitry (2014). "From Russian to Ukrainian Eurasianism: The New 'Historical' Friends and Enemies", Asian Ethnicity, 14(4): 449-466.

SIPRI (2014). "Military Expenditure and Arms Production", SIPRI Year Book, http://www.sipri.org/yearbook/2014/04, (accessed 14.01.2015).

Solonenko, Iryna (2009). "External Democracy Promotion in Ukraine: The Role of the European Union", Democratization, 16(4): 709-731.

Vitkine, Benoit (2014). "Vladimir Putin's Eurasian Economic Union Gets Ready to Take on the World", The Guardian, http://www.theguardian.com/world/2014/oct/28/eurasianeconomic-union-russia-belarus-kazakhstan, (accessed 28.01.2015).

World Trade Organization (2014). "Ukraine Profil", http://stat.wto.org/CountryProfile/WSDBCountryPFView.aspx?Country=UA\&Languag $\mathrm{e}=\mathrm{F}$, (accessed 10.02.2015).

Yıldız, Uğur Burç (2015). "Beş Yı1 Sonra Avrupa Birliği'nin Doğu Ortaklığı Politikası: Mevcut Durum ve Olasılıklar”, Uğur Burç Yıldız (ed.), Avrupa Birliği'nin Dış İlişkileri: Bölgesel Politikalar, Bölgeler ve Uluslararası Aktörlerle İlişkiler, Nobel Yayınları, Ankara, 2015: 141-162.

Zhurzhenko, Tatiana (2005). "Europeanizing the Ukrainian-Russian Border: From EU Enlargement to the Orange Revolution", Journal of Contemporary Central and Eastern Europe, 13:2: 137-154. 